\title{
Concerns with the use of Genelyn cadavers for surgical simulation
}

Sir,

We read with interest the article entitled, 'A cost-effective cadaveric model for plastic surgery simulation" ${ }^{\prime[1]}$ published in Indian Journal of Plastic Surgery. Whilst we appreciate the effort required to conduct this pilot study comparing microvascular flap surgery simulation using formalin and Genelyn cadavers, we have some basic concerns with the conclusion drawn by the authors on the basis of this study.

The authors describe Genelyn as a 'soft fixation technique' that gives cadavers live-like tissue quality, softness and 
flexibility. In contrast, a recent review defined Genelyn as a hard fixative that produces stiff tissues lacking colour as compared to fresh tissue. ${ }^{[2]}$ In agreement with this, Jaung et al. highlight significant difficulty with Genelyn tissue pliability and with the identification of surgical planes. ${ }^{[3]}$ Furthermore, Norton-old et al. note Genelyn tissue to be stiffer and more brittle as compared to non-embalmed tissue. Although there is a paucity of literature describing Genelyn cadavers, there is a general consensus that Genelyn tissue does not resemble living tissue. ${ }^{[4]}$

In theatre, it can be difficult for trainees to detect and isolate blood vessels pinnacle to flap survival, thus when we consider the caveats highlighted above with regard to hard-fixed cadavers, we can see how it may impinge on the potential of microscopic flap surgery simulation. If planes and structures cannot be appropriately visualised during training, how can one be expected to follow procedural steps, dissect and preserve structures? Where tissues are tough, how can one learn to handle with care or know the degree of pressure required for initial incisions?

Sidhu et al. discuss the importance of fidelity in simulation with regard to skills transferable to the operating room. ${ }^{[5]}$ Whilst we appreciate that Genelyn may be a more cost-effective alternative to Thiel or fresh tissue, we must not overlook the role of tissue fidelity and quality with regard to the development of transferrable microvascular flap surgery skills. Furthermore, it has been shown that Genelyn tissue is susceptible to mould, which can render cadaveric tissue unusable and should be considered when discussing cost. ${ }^{[3]}$

$\mathrm{Ng}$ et al. ${ }^{[1]}$ believe that Genelyn cadaveric material is 'sufficiently good for plastic surgery simulation' and suggest it as an alternative to Thiel cadavers. However, they have formulated this conclusion using a single trainee comparing Genelyn to formalin cadavers. When we consider that qualitative research is open to broad analysis, a greater sample size may provide more representative outcomes. Furthermore, formalin cadavers are well regarded as unsuitable for microvascular free flap dissection. As formalin shares many of the undesirable characteristics with Genelyn cadavers previously discussed, it would perhaps be more informative to compare Genelyn with fresh cadavers or soft-fix cadaveric materials currently used for flap surgery simulation. For example, a light embalming technique for fresh cadavers which uses weaker embalming solutions has been previously described. ${ }^{[6]}$ This technique boasts extended use ranging from 2 to 6 weeks (depending on storage temperature) as well as improved colour and texture of tissues.

Although the authors have demonstrated a cost-effective cadaveric model superior to formalin-embalmed tissue, the lack of research into the role of Genelyn tissue with regard to transferable microvascular flap surgery skills makes the benefit of such tissue unclear. In a surgical specialty dependent on sensory feedback and cues, it would seem a step backward to revert to Genelyn cadavers for simulation. However, as interest into plastic surgery simulation grows, surgical educators should strive to identify an appropriate embalming technique, which promotes cost-effectiveness whilst accurately resembling living tissue.

\section{Financial support and sponsorship}

Nil.

\section{Conflicts of interest}

There are no conflicts of interest.

\section{Tarak Agrebi Moumni Chouari, Karim El-Shakankery}

The Suttie Centre for Teaching and Learning in Healthcare, School of Medicine, University of Aberdeen, Scotland, United Kingdom

Address for correspondence:

Mr. Tarak Agrebi Moumni Chouari, The Suttie Centre for Teaching and Learning in Healthcare, School of Medicine, University of Aberdeen, Scotland, United Kingdom. E-mail: tarak.chouari.11@aberdeen.ac.uk

\section{REFERENCES}

1. Ng NY, Loh CY, Athanassopoulos T. A cost-effective cadaveric model for plastic surgery simulation. Indian J Plast Surg 2016;49:121-3.

2. Balta JY, Cronin M, Cryan JF, O'Mahony SM. Human preservation techniques in anatomy: A $21^{\text {st }}$ century medical education perspective. Clin Anat 2015;28:725-34.

3. Jaung $R$, Cook $P$, Blyth P. A comparison of embalming fluids for use in surgical workshops. Clin Anat 2011;24:155-61.

4. Norton-Old KJ, Schache AG, Barker PJ, Clark RA, Harrison SM, Briggs CA. Anatomical and mechanical relationship between the proximal attachment of adductor longus and the distal rectus sheath. Clin Anat 2013;26:522-30.

5. Sidhu RS, Park J, Brydges R, MacRae HM, Dubrowski A. Laboratory-based vascular anastomosis training: A randomized 
controlled trial evaluating the effects of bench model fidelity and level of training on skill acquisition. J Vasc Surg 2007;45:343-9.

6. Anderson SD. Practical light embalming technique for use in the surgical fresh tissue dissection laboratory. Clin Anat 2006;19:8-11.

This is an open access article distributed under the terms of the Creative Commons Attribution-NonCommercial-ShareAlike 3.0 License, which allows others to remix, tweak, and build upon the work non-commercially, as long as the author is credited and the new creations are licensed under the identical terms.

\begin{tabular}{|l|l|}
\hline \multicolumn{2}{|c|}{ Access this article online } \\
\hline Quick Response Code: & Website: \\
\hline & www.ijps.org \\
\cline { 2 - 2 } & \\
\hline
\end{tabular}

How to cite this article: Chouari TA, El-Shakankery K. Concerns with the use of Genelyn cadavers for surgical simulation. Indian J Plast Surg 2016;49:432-4.

() 2016 Indian Journal of Plastic Surgery | Published by Wolters Kluwer - Medknow 